January 2013

\title{
Civil Religion and the Cultural Politics of National Identity in Obama's America
}

Rhys H. Williams

Loyola University Chicago, rwilliams7@luc.edu

Follow this and additional works at: https://ecommons.luc.edu/social_justice

Part of the Sociology Commons

\section{Recommended Citation}

Williams, Rhys H., "Civil Religion and the Cultural Politics of National Identity in Obama's America" (2013). Social Justice. 53.

https://ecommons.luc.edu/social_justice/53

This Article is brought to you for free and open access by the Centers at Loyola eCommons. It has been accepted for inclusion in Social Justice by an authorized administrator of Loyola eCommons. For more information, please contactecommons@luc.edu. 


\title{
Civil Religion and the Cultural Politics of National Identity in Obama's America
}

\author{
RHYS H. WILLIAMS \\ Department of Sociology \\ Loyola University Chicago
}

\begin{abstract}
American civil religion (ACR) burst on to the scholarly scene in 1967, and has been periodically revived as a source of analytic insight and normative hope since that time. It posited a universalist, prophetic, nonsectarian faith, referenced on the nation, that served as both a source of unity for the American people and a discursive resource for political leaders and protest movements. Using recent political events as illustrative cases, I argue that ACR is not only a universalist, prophetic creed, it is also an expression of tribal identity that ascribes a particular character and purpose to the American people. In particular, this "tribal" civil religion has an oftenunstated assumption about the inseparability of religion, race, and national identity — that is, white, Christian, and American. Recent events have disrupted those implicit connections, leading to a vociferous reemphasis of their centrality to the national story. I maintain that neither ACR, nor recent politics involving immigration and Barack Obama's presidency, can be understood fully without considering the religion-race-national identity nexus.
\end{abstract}

Keywords: civil religion, political culture, national identity, Barack Obama.

\section{INTRODUCTION}

In a recent article (Williams 2011a) I made a case for thinking about "place" as involving both social and geographic space, and illustrated ways in which these dynamics shape religious expression and religious identity. I made this case using data from ethnographic research with second-generation American Muslims, and media reports on the highly charged controversy about the "Ground Zero mosque" in Lower Manhattan in the summer of 2010. The transition in place represented by immigration provided a social space for second-generation Muslim Americans to form an innovative form of both Islamic religious, and American cultural, identity. On the other hand, the materiality of the physical place that was the most associated with the $9 / 11$ attacks - the site of the former World Trade Center that became known as Ground Zero-provided the political context and the emotional accelerant for opponents to articulate an understanding of Islam as being outside the social space defined by American national identity. In this case, the blood of violence and death defined American identity; the land upon which that was inflicted became sacralized (Williams and Josephsohn 2012). That the blood, the land, and the national identity that made them meaningful was all "Christian" was a presumptive subtext that became manifest during the controversy.

Expanding on that insight in a second paper, I analyzed religious conflict as axially centered on issues of "blood and land" (Williams 2011b). In this case "blood" has two meanings. First, is

Acknowledgments: This is a revised version of the SSSR presidential address, delivered November 10, 2012, in Phoenix. For comments, critique, and suggestions both before the address and in the revising, the author thanks Lori Beaman, Mark Chaves, Jay Demerath, Janet Jacobs, Kelly Moore, Steve Warner, Richard Wood, and the members of the Sociology of Religion Working Group in the Department of Sociology at Loyola University Chicago. As the cliché goes-nonetheless true-errors of interpretation remain mine.

Correspondence should be addressed to Rhys H. Williams, Department of Sociology, Loyola University Chicago, 1032 W. Sheridan Road, Chicago, IL 60660,USA. E-mail: rwilliams7@luc.edu 
the importance of the literal and symbolic shedding of blood in physical sacrifice on behalf of a people, a cause, or a God. The language of martyrs and heroes, villains and victims, is infused with the physical reality of blood, and the symbolic connection to providing and denying life. Second, "blood" refers to the ethno-national sense of the "bloodlines" that are said to represent, as well as bind together, a genetic or primordial community-making communal identity something fundamental, ascriptive, and irrevocably set apart. Concomitantly, land represents the physical territory that a people inhabit and defend, but it also connotes the mythologized and hallowed land designated to that people by the gods (these often but not always overlap, as the study of people in exile shows). Blood and land are the central features of the axes around which extreme religious conflict flares.

Thus, in these two papers I made a case for the social and geographic realities of "place," and connected those realities to ethno-national religious solidarities that work to affirm collective identities as well as to occasion bloody conflict.

\section{Civil Religion}

This essay furthers the analyses ventured in those papers by examining their relevance to the venerable concept of "civil religion." As is the case with many concepts in sociology, civil religion is often more evocative than precise in its conceptualizations. In Bellah's (1967) seminal article, there is no formal definition, but rather a description and interpretation of a collection of phenomena that hung together and made immediate sense to many who study American public life. Not surprisingly, this launched a cottage industry of intellectual engagement that continues to revive periodically. Much of the concern has been definitional. For example, Coleman defined civil religion as "the religious dimension of the polity" (1970:67) or "the set of beliefs, rites, and symbols which relates a man's $[\mathrm{sic}]$ role as citizen and his society's place in space, time, and history to the conditions of ultimate existence and meaning" (1970:70). Meanwhile, Demerath and Williams stated: "civil religion denotes a religion of the nation, a nonsectarian faith that has as its sacred symbols those of the polity and national history" (1985:154). And Cristi, looking to expand the concept beyond the United States, notes that civil religions "sacralize certain aspects of civic life by means of public rituals and collective ceremonies" (2001:3). Although there exists some definitional variation (as with the concept of "religion" itself) the central thrust is clear-civil religion is composed of understandings and practices that treat the sociopolitical collectivity as having sacred dimensions and finds both its collective identity and its history religiously meaningful.

An important topic of contention is the role civil religion plays in collective social and political life. As many have formulated it, civil religion has been posited as a source of social and cultural coherence and even unity (see the reviews in Cristi 2001; Demerath 2003; Fuist and Williams forthcoming). It provides a set of beliefs, rites, and understandings that foster collective identity and gives that identity a transcendent meaning. Social diversity can be managed through this cultural canopy. A great deal of the critique of Bellah's original formulation was over this very point, on occasion forgetting that Bellah himself recognized internal ideological tensions in American civil religion, as biblical and utilitarian themes were both present and not always reconciled (see Cristi and Dawson 2007), and also understood how civil religion could be fractured (Bellah 1975). Others have posited competing civil religious traditions, one prophetic and critical, the other celebratory and approaching religious nationalism (Marty 1974; Wuthnow 1988). Another critique was less convinced of civil religion's existence as a "social fact," and described it instead as a "legitimating myth" (Hammond 1994) or a "discourse" (Demerath and Williams 1985; Williams and Alexander 1994) used by a variety of political and social actors to place themselves within American traditions and add persuasive symbolics to their claims. In 
these cases, civil religion was often parsed analytically as either "culture" or "ideology" (Cristi 2001; Cristi and Dawson 2007; Williams 1996).

Marvin and Ingle $(1996,1999)$ take a different tack. Rather than separating nationalism and religious sectarianism they examine the two phenomena for their similarity-it is the felt obligation of a literal "blood sacrifice," that is, the willingness to shed our own blood to preserve the sacred from threat. Blood sacrifice sanctifies the nation as martyrdom manifests the sacred character of the religious community. These essentially religious acts are also essential to community solidarity. They are "nationalism" when they are nation building, and the collective identity being thus formed is a national one. Far from Anderson's (1983) idea of the nation as an "imagined" community, Marvin and Ingle's (1996, 1999) powerful argument claims that national communities are actually sacrificial communities, and are thus analytically indistinguishable from religious communities (on the essential connectedness of nationalism and religion, see Smith 2003).

But while Marvin and Ingle $(1996,1999)$ make a strong case that only violence can produce enduring group unity, they still posit civil religion as basically about producing such unity. Blood, in their view, is the means through which group cohesion happens. In contrast, I call attention here to the extent to which "blood"-and the "land" to which it is connected-are integrally part of the content of civil religion. Civil religious understandings of blood and land, and how they constitute tribal identities, have particular relevance for American national identity. The intersection between religion and race, manifested as concerns for protecting ethno-religious bloodlines and divinely granted land, connect two recent political controversies-debate over immigration to the United States and the expressions of political opposition to President Barack Obama that accuse him of not being truly "American," including the supposed questions of whether he was born in this country and whether he is a Muslim.

\section{The Character of American Religion}

The claim that "blood and land" are integral to religious identity and are central to some of our recent political turmoil, calls into question one explanation as to why religion has been so successful in the United States. Although seldom offered as the solo cause for American religious vitality, many scholars point to the importance of the deterritorialization of religion-and the accompanying deterritorialization of ethnicity in the United States. As far back as historian Frederick Jackson Turner's (1893) "The Significance of the Frontier in American History," the "frontier" has been seen by many as key to American identity and the success of American society. ${ }^{1}$ The nation could continue to expand, allowing for reinvention and innovation, and simultaneously weakening the boundedness of tradition and the past. As a result, American religion is innovative; it is mobile in a culture that is always on the move, it prospered in a frontier society where established societal institutions - with their hierarchies, their embedded conflicts, and their cultural inertia—-were left behind by people who were reinventing themselves and in the process reinventing their forms of religious expression. The New World, this argument goes, simply does not have the history for-and had too much geographical room to allow-the entrenched loyalties and hatreds that have marked other places and nations and have often resulted in territorial violence.

Versions of this claim appear in a number of influential works that have shaped much of our current understandings of the character of American religion. For example, Hatch's influential

\footnotetext{
${ }^{1}$ I recognize the debate among historians regarding Turner's thesis. My point here is the consistent claim that the geographic and social frontier had important consequences for the United States, one of them being the breaking of the link between territory and ethnicity.
} 
The Democratization of American Christianity (1989) and Moore's Religious Outsiders and the Making of Americans (1987) show this dynamic at work without naming it as such. Similarly, Finke and Stark's The Churching of America (1992) and Warner's seminal "New Paradigm" article in the American Journal of Sociology (1993) both have arguments with these implications, even if not as their central focus. The dynamic of mobility, both geographic and social, fosters reinvention and innovation and is part of the "American exceptionalism" argument (when it is used as an analytic insight; cf. Lipset 1996). The United States has remained religious even as it has modernized, unlike much of Western and Northern Europe, because of structural, geographic, and cultural factors that created an open market in religion and facilitated a pluralist civil society. When religion in the United States is shown as being territorial and violent, as for example in McGreevy's (1996) story of the struggle of Chicago's ethnic Catholic parishes with racial integration, this is presented as an unfortunate failing. The current burgeoning literature on religion and immigration, with its many stories of adaptation and syncretism (e.g., Warner and Wittner 1998; Williams 2002), helps support this basic perspective of the fluidity and adaptability of American religion, even as it helps to form new "Americans."

In what may be an odd theoretical pairing, I would add to the scholars named above, Bellah (e.g., 1967, 1991) and his notion of American civil religion. I recognize that the streams of scholarship often labeled as the "new paradigm" approach or the "religious economies" model are in some ways antitheses of the type of Durkheimian-influenced sociology that Bellah's work represents. Bellah was engaging a theoretical tradition that also produced the "sacred canopy" formulation voiced by Berger (1967); that is, how can a society survive without an integrating cultural system that is anchored in the transcendent? Neither Bellah nor Berger were trying to explain the vibrancy of American religious diversity and its connections to cultural mobility, but rather were exploring the potential crisis in social solidarity that was thought to follow that very pluralism. The "sacred canopy" and the "religious economies" approaches emerge from competing traditions in social theory, and presume different understandings as to how religion works.

But in my view these varied scholars were all trying to wrestle with a similar problematic regarding American society. That is, how can American society remain so religious, especially as modernization is simultaneously accompanied by social and religious pluralism? Why has the institutional "religionlessness" of other economically developed nations not been replicated here? And what role has religion played in maintaining social solidarity? From Bellah to Warner, these accounts conclude that religion has had a positive, and in many ways integrative, impact on the national situation. For "new paradigm" scholars, disestablishment allowed pluralism to flourish and let the varied groups within society find a religious expression that suited their needs. "Religion" maintained its legitimacy as long as a single dominant faith was not imposed on all citizens. For Bellah, sacralizing dimensions of the polity and national history shifted the gaze away from sectarian differences and gave a common point of allegiance. As a result, religious congregations became the most common of civil society organizations, and are the place where more Americans hold self-identified "memberships" than anywhere else. They become where Americans meet each other in voluntary circumstances and this fosters tolerance and acceptance (see Putnam and Campbell 2010). Alternatively-but often in complementary form-religious ideas and worldviews form a founding and legitimating mythology that helps to symbolically create and shape American peoplehood as well as reinforce a stable polity. Religion, it is argued, has been key to American social progress and political success, and a key part of the nation's ability to deal with diversity (e.g., Warner 2008). Unity is combined with pluralism.

I am not hostile to this perspective on and characterization of American religion. The research I have been doing with second-generation Muslim Americans leads me to conclude that they use their location in a new country, and the social and geographic mobility it provides, to develop a hybrid or hyphenated culture as well as a distinct form of their religion. They are at once being faithful and innovative (Williams 2011a; Williams and Vashi 2007). There is further evidence of 
this American diversity and tolerance in the immediate response in the United States to Muslims after the attacks of September 11, 2001. Certainly, there were cases of harassment, discrimination, and violence directed at Muslims and others who appeared to be Muslim. But that reaction was shaped by American cultural individualism in a way that worked against the potential for collective violence (see Williams 2010). Without discounting the backlash that did occur against American Muslims (Peek 2011), there has not been the communal religious violence in the United States that has marked interreligious conflict in India or Nigeria or Northern Ireland-or that was directed in the United States for decades at African Americans.

Nonetheless, this expansionary and optimistic view of American religion-while still holding in many ways - is also challenged by dimensions of religion emerging out of our less expansionary and optimistic times, and in very different global circumstances. A series of historical events has interacted with the ethno-religious dimensions of religious identity and precipitated a crisis in America's tribal civil religion. Simply put, what many Americans see in Obama's racial and religious status is a disruption of a civil religious connection among religion, race, and national identity. There has long been a sub rosa association that made "white Christian American" the baseline, default cultural understanding of this nation (see, e.g., Williams 2004 on religion in the Midwest). Obama's election encapsulated for many people their fears regarding social changes that threaten those connections and their resentments over a potential redistribution of what Weber (1958) would call "social honor" in American society. This disruption has occurred at the same time that new immigrants to this country have become a national, rather than a regional, population and as the conviction that this immigration is a significant social problem has become a major part of the Republican Party's electoral platform. And all of this has most recently developed with the events of $9 / 11$ as the political backdrop and the catalyst for the emergence of a significant religious "other." These events are related in that they form a swirl of social and religious change that has enabled and amplified a decidedly nonuniversalist, and nonunifying vision of the nation's religious culture-our "tribal" civil religion. I consider these issues in turn, with attention to how the intersection of religion, race, and American identity has made them part of a vortex of sociocultural and political change and challenge.

\section{9/11, Ground Zero, and Religious Pluralism}

The attacks of September 11, 2011 are the political and cultural backdrop to the general dynamics (both political and religious) I explore here, but they also have direct civil religious relevance. First, not surprisingly, the immediate aftermath of the attacks produced the type of patriotic and civil religious response that accompanies most major "events" in American society and history-whether the Iranian hostage crisis in 1979, the space shuttle Challenger explosion in 1986, or the devastation wrought by Hurricane Sandy in 2012. Following such events, the U.S. president typically appears in public immediately to assure the nation that this will not permanently damage our society or our way of life, and asserts our national resolve to deal with the disaster. Further, he typically claims that the resilience just asserted itself reveals the basic strength of our national character and the goodness of our people. The president evokes civil religious blessings on the country that serve to remind us of our national relationship to the Divine. There is usually a "rally around the president" effect in public opinion, and approval ratings for the president typically increase dramatically in the immediate aftermath of the event.

We saw these things in dramatic form after 9/11, from President George W. Bush's soaring approval ratings, to his rhetoric of resilience and rebuilding, to the ubiquitous flourishing of posters, bumper stickers, billboards, and the like that proclaimed "Proud to be an American," "God Bless America," or "United We Stand." It is important to note that the president must do these rites of civil religious healing successfully-President Bush's response to Hurricane Katrina in 2005 is an instructive counterexample. He was viewed as detached, slow to respond, 
and then uncaring when he did issue public statements; it was the opposite of the performance that marked the 9/11 aftermath and public opinion regarding his presidency turned negative.

Another dimension of the response to a disaster event is the search for, and designation of, the responsible "other" to blame. Immediately after $9 / 11$ there were a number of widely reported acts of violence against Muslims, their houses of worship, and people who looked like or were mistaken for Muslims. (As in the well-known example of the Sikh man murdered in a Phoenix suburb by an Anglo-American who reportedly shouted "I stand for America all the way" as he fired. After murdering the Sikh owner of a gas station, the gunman later shot at a Lebanese-American clerk at another gas station, and fired into the home of an AfghanAmerican family. The shooter had also reportedly been complaining about immigrants and "towelheads" both before and after the September 15th murder.) However, while Muslims were quickly identified as responsible for 9/11 attacks, there was not large-scale collective physical violence against Muslims or against mosques. Without justifying or dismissing what did occur, it is not difficult to imagine that the immediate backlash could have been much worse. Some credit, I believe, should go to President Bush, New York City Mayor Rudolph Giuliani, and other political leaders who went out of their way to separate rhetorically the terrorists who attacked the nation from Muslims and Muslim Americans in general (Singh 2002). Many governmental leaders called for restraint and warned against retaliatory backlash. Further, President Bush had deep connections to the oil-producing parts of the Arab world, and had a moderate record on immigration issues; in general, the Republican Party initially followed his lead immediately post-9/11.

This claim is not to dismiss the injustices perpetrated on Muslim Americans, other darkskinned Americans mistaken for Muslims, or, indeed, the damage to the Constitution inflicted by the passage of the USA PATRIOT Act and other aspects of the developing "security state" apparatus in the years following 2001. But as Bakalian and Bozorgmehr (2009) note, it was not the immediate backlash in civil society that threatened the new lives being created by Muslims in the United States, but rather the responses by state agencies in the name of security over the next decade (see also Williams 2010). Further, compared to the current Republican Party's response to Islam, Muslim Americans, and immigrants, the immediate actions of President Bush, Mayor Giuliani, and other political leaders in 2001 and 2002 appear moderate and reasonable.

This has clearly changed. In 2010, there was a seeming eruption of controversies over efforts by Muslims to build mosques in the United States. The best known was in New York City at the World Trade Center site, but there were also heated controversies in Tennessee, Kentucky, Georgia, California, Pennsylvania, Illinois, Wisconsin, and elsewhere. Renee Ellmers, a Republican congressional candidate in North Carolina in 2010, ran television ads accusing her opponent of supporting the Ground Zero "victory mosque." Conservative Republicans such as Representative Michele Bachmann of Minnesota and Representative Allen West of Florida (the latter of whom was narrowly defeated in 2012) both openly expressed hostility toward Muslims and Islam and voiced suspicion about their activities in America (e.g., Rayfield and Seitz-Wald 2012).

Given the relatively restrained response to Muslims in the United States immediately following 9/11, it seems curious that such a backlash would emerge as a potent political force almost a decade later. I posit three reasons for the timing of the concerns. First, the controversies over mosque building involve the very materiality of place, and the symbolic permanence and seeming acceptance that are implied in building houses of worship. Particularly in New York, the buildings lost and the new ones proposed, and the visual representation of loss and how that should be commemorated (direct issues of blood and land) sparked intense emotion (Williams 2011a; Williams and Josephsohn 2012). Controversies at sites in other cities and states often evoke the emotions generated by the Ground Zero controversy, with each newly proposed building itself representing and focusing deep concerns about terrorism and national security, and American identity as a 
"Christian nation." One such concern is the worry about the implementation of Shari'a law in the United States. ${ }^{2}$

A second factor accounting for the belated rise in anti-Muslim hostility is the increasing conservatism of the Republican Party following the end of the second Bush administration, especially around issues of immigration (Williams 2012). By 2008, the Bush administration and the president himself were being criticized on many fronts. Two costly wars seemed to continue to drag on, and the economy imploded in near financial catastrophe. The perception of incompetence that followed the administration's response to Hurricane Katrina moved into other areas of domestic, foreign, and economic policy. Ironically, the failings of the Bush administration tarnished the Republican brand with conservative Republicans as much as it did with moderates and Democrats, if for different reasons. This dissatisfaction helped foster the rise of the TEA party, whose electoral victims have mostly been moderate Republicans, and has led many to reject any sense of political compromise, while moralizing politics into a Manichean conflict of good and evil (Skocpol and Williamson 2012).

The third explanation for the increasing hostility toward Muslims in the United States is the increasing prominence of anti-Muslim and anti-Islam messages in the media, including resentments emerging out of the Afghani and Iraqi wars. Bail (2012) has done an interesting and sophisticated "ecological" examination of press releases about Islam produced by civil society organizations, and the media coverage they received, from 2001 to 2008 . His basic finding is that a media message of "Muslims are enemies" was a distinctly minority frame existing on the fringe of mainstream media coverage in 2001; however, it became a much more "mainstream" message in media coverage about Islam over the next seven years. For a variety of reasons, anti-Islam media messages received increasing coverage by the mainstream media over time following 9/11. Our national political culture, in general, became more hostile to Islam over the decade following 2001 - with a clear result that for many Americans there is now a more distinct religious "other."

Thus, I argue that 9/11 was a civil religious event, but one that was rooted in blood and land, and for which the role of violence in the event, and in responses to it, needed to be accounted for. Over time, the dynamics of national pride and resilience became accompanied by a tribal "othering" in which an enemy has been increasingly identified by those who are most convinced that American blood and American land are under attack.

\section{Immigration in American History and Politics}

The post-9/11 shift in the public discourse about Muslims and Islam coincided with an increasing hardline conservatism regarding immigration, another issue in which there is a blending of religion and race in a civil religious understanding of who can be an American. Of course, immigration has had a long history in American politics, but not a consistent or predictable one. It has waxed and waned as an issue in different historical periods and it has varied regionally with the changing characteristics of immigrants. This has often produced cross-cutting political cleavages, wherein conservative nativists have opposed loose immigration laws even as conservative business interests have favored them. Conversely, social liberals have taken proimmigrant stands as a sign of a commitment to diversity, even as many labor organizations have been suspicious of immigration's effects on wages. For these reasons, for many years, immigration would be an issue during presidential primary seasons, as candidates played to different segments of their party, but largely disappear in the general election because candidates did not want to disrupt their party coalition (in this regard, immigration has been distinct from abortion-a polarized,

\footnotetext{
${ }^{2}$ For example, Oklahoma passed a law in 2010 forbidding courts from using Shari'a law when making decisions; controversies over mosques and Islamic centers are catalogued in Pew Forum on Religion and Public Life (2012).
} 
national, "culture war" cleavage issue since the 1970s; abortion is not much of a primary issue since each party has a pretty clear consensus, while it is a significant general election issue). But immigration has become in the last decade a more national issue (as new immigrant communities expand from traditional "destination" areas into more parts of the country); simultaneously, it has become a more polarized and salient issue as well (Williams 2012).

It is often observed that debates over immigration represent an ongoing debate over "who counts as an American?" (e.g., Theiss-Morse 2009; Zolberg 2006). Although there has been some variety in the reasons nativists have protested that newcomers are "not fit for our society" (Schrag 2010), the grounds have overwhelmingly centered on religion, race, and some combination of the two. Religious differences are particularly emphasized in accounts of 19th- and early 20th- century immigration. For example, histories of the immigration conflict in the 1840s-1860s focus on the large numbers of Catholics among the Irish and German arrivals. Nativist reaction to this immigration highlighted temperance and Bible reading (either in schools or as a theological matter) and the threat to democracy posed by allegiance to the Roman Church (e.g., Sarna 1998). Although many histories point out that class, language, and nationality often intertwine with religion (e.g., Schrag 2010), the role of religious difference in prompting 19th- century "Know-Nothing" nativism was quite salient.

Similarly, studies of the so-called second wave of European immigration to the United States (approximately 1880-1920) often note the extent to which the predominantly Eastern and Southern Europeans were Catholic or Jewish. In many histories, the immigrants' faith is crucial to the story (e.g., Orsi 1985), and accounts of the rise of nativist organizations, such as the 1920s Ku Klux Klan (McVeigh 2009) or the 1890s American Protective Association (which was quite explicitly anti-Catholic and largely populated by Irish-American Protestants; Bennett 1988) note the extent to which anti-immigrant, anti-Catholic, and anti-Semitic sentiment went together. Again, Catholicism was seen as inimical to democracy, with parish Catholics something of an invading army set on undermining the public schools, America's isolationist foreign policy, and in general disrupting the structure of privileges and status that went with being of Anglo-Saxon Protestant descent. Two notable histories about immigrant communities that were able to "become white" in the American racial order are simultaneously stories about religious difference and marginality — that is, Brodkin (1998) regarding Jews, and Ignatiev (1995) on the Irish (particularly Irish Catholics). Thus have religious and racial status been comingled in the history of immigrant incorporation in the United States.

Attention to the most recent bout of nativist opposition to immigration has been much more focused analytically on race (e.g., Jacobson 2008; Newton 2008). The attention to the ways in which racialized conceptions of the other continue to matter in American culture and politics, and analyzing the use of "color-blind" techniques by the self-described "immigration reform movement" to defuse potential charges of racism, is a welcome development. Nonetheless, I argue here for greater attention to the extent to which racialized images of immigrants are bound up with religious and cultural identity and a civil religious sense of who is "really" American.

Currently, there seems to be a set of standard concerns that produce arguments for restricting immigration (e.g., Reimers 1998; Williams and Park 2005). For example, there are economic arguments - such as the claim that immigrants "take American jobs," or that they cost taxpayers due to their use of public services. Since $9 / 11$ one can find security arguments regarding terrorism and appeals to "law and order" (emanating from the position that undocumented immigrants are by definition breaking the law, as well as the claim that immigrants are responsible for crime). Significant for my argument here are the concerns about immigration due to worries about American cultural identity, and indeed, worry that the existence of the United States as a cohesive, unified society may be at stake.

There is significant evidence that these "cultural politics" of immigration are crucial. A number of social science studies have found that those Americans who are most concerned 
about immigration as a social and political problem are also deeply worried about preserving "American" identity. That is, for those people for whom immigration is a highly salient and emotional political issue, concern for cultural identity outweighs other possible objections (such as economic arguments). The best example of this among the political class is Huntington's Who Are We? (2004), which makes an explicit case for the necessity of Anglo-Protestant culture as the basis of American national identity. But similar themes can be found in studies of American public opinion about immigration (see a review of some of this literature in Williams 2012). Collectively, a number of studies provide evidence that when immigration emerges as a political issue it becomes conceptualized, articulated, and gains salience as a cultural issue.

Further, as I have argued elsewhere (Williams and Park 2005, 2006), when concerns about immigration and American culture are articulated, "culture" often assumes many of the properties that we often associate with "race." That is, culture is described as inherited, fundamental, ascriptive, and immutable. Culture, in this view, is not something humans "do"-it is something humans "have" or "are" in ways seemingly resistant to change. Who we are is cultural, in the sense of ethno-religious culture, and it depends on a fundamental similarity. Diversity divides, and too much ethnic diversity — and its celebration through "multiculturalism"- threatens to weaken the national fabric.

It is worth noting, however, that even the economic and security arguments for restricting immigration have cultural dimensions, based on notions of who belongs in the American community. Economic arguments usually involve claims that immigrants take jobs from or lower the wages of "American" workers_-people who are citizens. The security arguments sometimes involve explicit reference to terrorism but more often are encapsulated in calls to "seal the border" or "stop the invasion." The mixture of "citizen" and "border" talk is revealing: "citizen" is at base a legal status, but sociologically it is fundamentally about belonging, and recognition by other members of the community (Glenn 2011). Even the legal status of citizen depends implicitly on borders and their meaningfulness in defining the "homeland." Borders, when meaningfully regulated by sovereign authority, separate peoples and delimit cultures, all of which works to guarantee identities (Brown 2010). As such, borders help constitute the "social citizenship" that forms the "national imaginary" (Somers 2008). Thus, even when cultural unity is not the manifest argument for restricting immigration, there is a cultural argument embedded in the economic rationales, the law-and-order rationales, and the seal-the-border rationales, all connected through the notion of the "citizen" as one fully entitled to societal membership.

\section{Barack Obama and the Cultural Politics of American Civil Religion}

Having examined the backdrop of $9 / 11$ and the civil religious politics of nationalism that followed it, and made a case for the cultural foundations of the politics of immigration-a cultural foundation that blends racial and religious criteria in considering who should be allowed to immigrate here and their relative threat to American identity-I turn now to the cultural politics surrounding Barack Obama and the opposition to his presidency.

There is no doubt that the election of Barack Obama to the presidency in 2008 was a momentous event for the American civil religion narrative. When fewer than 50 years earlier the election of a white Catholic to the presidency was seen as a major step in American diversity, the election of a man born to an African father and a white American woman was difficult to view without some amount of awe. In the thrall of those emotions, many media headlines declared the United States to now be in a "postracial" period, and even many on the cynical left (especially in the academy) could not help but experience a feeling of triumph and the hope for a new day-especially given the size of his first victory. Even some moderate conservative commentators proclaimed a certain American victory in Obama's election, marking the end of 
racism as a particularly malignant stain on the character of the body politic. One need not accept the postracial hype to see this as a major event. ${ }^{3}$

At the same time, Obama's election also singularly disrupted the implicit cultural triangle of race, religion, and national identity that I am arguing is foundational to American civil religious mythology. There are two responses to this disruption, distinct but related, of particular interest to me here. First is the "birther" controversy over whether Obama was actually born in the United States, making him the "natural born citizen" that is one of the constitutional requirements for the presidency. A second response has been the resonance and persistence of the idea that Obama is a Muslim. Although it is tempting to dismiss these persistent beliefs as the result of the fabled American political ignorance (as H. L. Mencken is reputed to have remarked- "no one ever went broke underestimating the intelligence of the American public"), I take these beliefs, their persistence, and the willingness to voice them publicly seriously as an expression of the cultural turmoil resulting from the disruption of the civil religious connections between blood and land.

During the 2008 presidential campaign season the issue of race was generally treated much as it is in American culture at large - it was both an ever-present and a rarely mentioned phenomenon. Notably, the only public speech Obama made about race was also connected to religion, as a response to the controversy following the appearance of a number of videos and interviews that showed the Rev. Jeremiah Wright, senior pastor at Obama's church, expressing anger at the United States for its history of racial oppression. Although there was widespread dismay at the vehemence of Wright's language, particularly in a campaign season, Obama's critics saw deeper significance in the episode.

For some commentators the key issue was that Wright was an advocate of "Black Liberation Theology" (e.g., Jon 2008; WorldNetDaily 2008), and they accused Obama of holding the same ideology. Conservative blogger Marie Jon (2008) wrote:

\footnotetext{
Barack Obama belongs to an unabashedly Black African-centered church. Its teachings focus on a "black value" system. It has knowledgeable Americans questioning how Obama's church . . . and its pastor ... influence the man who wants to be President of the United States.... Why couldn't Obama have chosen to be a Methodist, a Pentecostal or a Lutheran? What drew him to a church that many find questionable?... The nagging question begs to be answered. Why would the top Democrat presidential candidate feel more comfortable attending an Afrocentric church? Obama's attendance at a church that encourages blacks to separate themselves from the rest of American society must be explained. How can he claim to be able to unite and reach across to all the people in the nation?
}

Wright's quoted remarks directly flew in the face of any congratulatory construct of America's place as divinely chosen - in fact, they singled out the United States for specific and particular critique. Further, they contrasted black and white America, holding the latter to account for many of the ills of the former. But that very set of criticisms, articulated by Wright as an expression of anger for past injustice, and accompanied by the claim of divine justification for that anger, were deemed by many as making suspect Obama's qualifications to be president. The implicit claim was that American racial history is currently irrelevant and that black critiques of white America are unpatriotic.

This episode, and the birther agitation, and the charges that Obama is Muslim illustrate how racial identity has been intertwined with religious identity and civil religious assumptions as part of the consistent construction of Obama as "other"- as in some way not truly American, whether the criteria are articulated as involving citizenship, native-born status, or cultural understandings.

\footnotetext{
${ }^{3}$ Many in the world of political punditry, and many news analysis themes, reprised this self-congratulatory rhetoric after Obama's reelection in November 2012. For many, the reelection marked a victory for tolerance, diversity, and a new America.
} 


\section{Birthers}

The "birther" claim that Obama was not born in the United States began well before the 2008 election and continued to generate headlines and news interest into the 2012 primary season. Birthers have made continual demands (via venues that run from billboards to lawsuits to Donald Trump publicity gimmicks) that Obama produce an "authentic" U.S. birth certificate. These demands have appeared along with allegations (and the occasional "proof") that he was born in Kenya.

The birther position thus literally describes the president as a noncitizen, or at the least not a "native-born" citizen that meets the Constitution's definition of who may be president. His failure (reputedly) to be born on American land invalidates his claim to status as legitimate political authority. Moreover, the important subtext is about Kenya-a sub-Saharan African country with a significant Muslim population (in several publicized forged copies of Obama's "Kenyan" birth certificate, the city of birth was listed as Mombasa-Kenya's most heavily Muslim city). Presenting President Obama as a Muslim from sub-Saharan Africa links Obama to what is a religion to be feared in a part of the world typified by violence in the American mind, and it racializes Muslims by associating them with what is for many a stigmatized racial identity (an analysis of racialized citizenship themes in the birther arguments is in Hughey 2012). In both cases the claim casts Muslims as not truly American. The claim takes advantage of post-9/11 American fears of Islam and makes Obama irrevocably "foreign." Further, charging that the president was born in Kenya also makes him an "immigrant." This theme has appeared on numbers of placards at anti-Obama rallies-some demanding that he "go back to where he came from," or another one with a picture of the president over a caption that reads "undocumented worker" encapsulating both opposition to immigration and to Obama by marking them as foreign.

\section{Obama as Muslim}

The opposition to Obama has often represented the president with racialized and blatantly racist images. Some are direct, such as the t-shirts seen at Romney-Ryan campaign events that said "Put the white back in the White House" or the bumper sticker that urged voters not to "re-nig." Some messages and especially many of the images are quite shocking and very distressing - the number of photo-shopped images on the web that turn the president and sometimes his family into a monkey or a chimpanzee is staggering. This is distressing, no doubt, but I do not think that it should surprise analysts of American politics and culture. The growing identification of the Republican Party with white America, and its primary electoral stronghold in the same part of the country that had a racial apartheid system less than 50 years ago, makes this unfortunately inevitable. Race is built too deeply into American life and the structure of American politics. With an expansion of political incivility and an expansion of access to media production - that is, the ability of many citizens to generate political content through blogs, websites, and social media-that opposition to the first African-American president would have racial dimensions is (unfortunately) not "news."

But the persistent contention that Barack Obama is not truly American, and moreover, is a Muslim, is analytically fascinating-particularly because the persistence of this claim (like the birther claims about Obama's citizen status) flies in the face of available, conventional evidence. It may be deplorable that the right wing often voices its opposition to the president in racial terms, but it is neither surprising nor counterfactual. Although Obama did not have the background or

\footnotetext{
${ }^{4}$ A good example appears in a photo by Bob Simmons, which may be viewed at http://www.flickr.com/people/tuaussi/. A woman holds a sign with a picture of Obama above the words "undocumented worker" at a Tea Party anti-tax rally on September 12, 2010, on the Capitol Mall, in Washington, DC.
} 
experiences of many African Americans, the idea that he codes as a black man in American society is pretty well beyond dispute.

But he is not a Muslim. He is a baptized Christian, was married in a Christian church, and has talked repeatedly about his Christian faith. A major controversy in the 2008 presidential election campaign, noted above, focused on the Christian congregation of which he was a member. Obama campaigned regularly in churches during 2008, regularly testifying to his own faith. The White House has released numerous photographs of the First Family going to church on Sundays.

Yet the Muslim claim persists. I "Googled" the phrase "Obama is a Muslim" on November 2, 2012, and got 226 million links (in contrast, my Google results for "Obama is a socialist" revealed just under 60 million links, "Obama is a Nazi" 56 million links, "Obama is a liar" 58 million links, and "Obama is an illegal immigrant" produced 74 million links). Some of these links, of course, are media commentary on the Muslim claim; but that commentary itself is a measure of the resonance and perseverance the claim has had in American politics. Further, any search of the Internet can find many websites and political blogs that traffic in all manner of photo-shopped images portraying the president as Muslim. One, for example, plays off of Shepard Fairey's famous image of Obama from the 2008 campaign, but puts him in a keffiyeh scarf such as that famously worn by Yasser Arafat. Another uses Alex Ross's painting of Obama as Superman-pulling off his shirt and tie to reveal a blue uniform underneath with a large "O" where Superman's " $S$ " would be-but that $\mathrm{O}$ is transformed into a crescent moon and star (a sly reference to the clandestine nature of Obama's faith despite his appearances to the contrary). Another image mimics the flag of Saudi Arabia, but rather than the words of the shahada (the Islamic declaration of faith) written in white, above a saber, on a green field, the words read "barack hussein obama" in a stylized, Arabic-looking script. Examples could go on and on. Most of these images, such as the one that puts Obama's face into a Lawrence of Arabia movie poster in place of Peter O'Toole and titles the film "Hussein of America," associate Obama with the countries or culture of the Muslim/Arab Middle East, rather than the Muslim country where he did live, Indonesia, or the country where he was reputedly born, Kenya.

The plethora of images and Internet memes that a Google search can surface emanate from people active enough in politics to want to register their displeasure that publicly. However, the notion that Obama is a Muslim is deep in American public opinion. The percentage of Americans who believe that President Obama is a Muslim-or who tell pollsters that they are "not sure" whether he is Muslim or Christian-has increased, not decreased, with the increase in the publicity and available factual knowledge that he is not Muslim. For example, the Pew Research Center gathered data at three points in time: 2008, 2010, and 2012. It found the number of Americans who believe Obama is Muslim increased after his first election, and remained steady through 2012 (Pew Research Center 2008, 2010, 2012). Equally revealing was a March 2012 survey of likely voters in the Alabama and Mississippi Republican primaries, produced by the firm Public Policy Polling (2012). Those numbers showed slight majorities - again of likely voters in southern Republican primaries, the most conservative of Republicans-who believed Obama is a Muslim and significant numbers of others who answered "not sure."

There are reasons to doubt whether that many Americans truly think the president is Muslim. For one thing, the percentages who actually believe him to be a Muslim in the Pew national surveys first increased right after Obama's first inauguration and then remained more or less constant (from 12 percent in 2008 to 19 percent in 2010 and 17 percent in 2012). What fluctuated more dramatically was the number of people responding they "do not know" (31 percent in 2008, 41 percent in 2010, and 31 percent in 2012). Those percentages mirror the president's general approval ratings and the perceived health of the economy, and correlate with the age and level of conservatism of the respondents. Even so, they are almost a third of the electorate. What is entirely plausible is that a significant percentage of respondents answered in the affirmative or "not sure" in order to register their displeasure with the president and his perceived policies. Conservatives, and especially highly religious conservatives, are expressing their disapproval of the president 
and their distinct feeling that he is not "one of us" by identifying him as "Muslim"-using that category as something irrevocably other and fundamentally suspect. They disagree not just with President Obama's policies, but suspect that his religious identity is not what they consider normatively "American."

An aspect of the religious dimensions of opposition to Obama that became particularly interesting in the 2012 presidential campaign is that those Republican voters who are most conservative and most strongly identify with evangelical Protestantism are also most suspicious of Mormonism (Kornacki 2012). Considering the history of American religion, and especially the history of the Latter-Day Saints, it is remarkable in many ways that a candidate for president from a major political party was Mormon. For much of its existence, the Mormon faith has been regarded by American Protestants as not Christian (cf. Penning 2009). Indeed, until recently, even such a centrist evangelical figure as the Rev. Billy Graham had Mormonism described as a "cult" on his website (a designation not removed until Graham had a personal meeting with Romney; Burke 2012) and surveys still report many evangelicals do not recognize Mormonism as "Christian." Yet the party of evangelical Protestantism nominated a Mormon for president.

So why was Mitt Romney's actual religious identity not a major political or cultural issue, compared to Obama's fabricated identity? Certainly, Mitt Romney as Governor of Massachusetts and as presidential candidate worked to downplay the differences between his faith and Protestant evangelicalism, most prominently in a speech given during the 2008 Republican primary season. Also, Mormons score high on most measures of social conservatism, so that they have become a reliable Republican voting bloc. And the Latter-Day Saints Church leadership worked with the Roman Catholic hierarchy in campaigning for California's Proposition 8 (an effort to curtail the civil rights of gays and lesbians) in 2008 (Riccardi 2008). These moves have politically aligned the Latter-Day Saints Church and Mormons generally with conservative Catholics and Protestants.

Beyond these political affinities, in a more fundamental cultural alignment, the Mormon faith has lionized the United States with a version of celebratory American exceptionalism and religious nationalism. Aspects of Mormon theology can play into an historical theme of American identity as a "chosen people" (e.g., Hughes 2003; Smith 2003), and Romney himself practically elevated a priestly civil religion into his proposed foreign policy-from his book No Apology: The Case for American Greatness (2010) to his frequent charge that President Obama traveled all around the world apologizing to other countries for the U.S. misdeeds. Romney's religious "American-ness" - in effect, a civil religious assertion of the special character of American blood and land-diffused and defused theological differences among conservative Christians.

This resonates with another source of suspicion and distrust of Obama-that is again, in my view, connected to the birther and Muslim constructions. Obama is often faulted for the international character of his life story, and the cosmopolitan character of his personal habitus in the world. Obama seems comfortable in many places and cultures, moving easily in settings such as the Ivy League, the U.S. northeastern seaboard, the Middle East, Asia. And distinctly uncomfortable in other prototypically "American" settings, one dramatic example of which was an attempt at bowling (Barrett 2008). His comfort in the world outside the United States distinguishes him yet again from many Americans, even among the political class.

For many Americans a cosmopolitan, internationalist perspective is a violation of the assumption that the United States is special, distinct, and uniquely chosen. Part of our foundational mythology is the idea of Americans coming out of a fallen Old World in order to create a new Zion. A return to the Old World, or considering other regions of the globe as rivaling the United States in importance or virtue, fails to keep faith with that commitment and vision. "American exceptionalism" recently went from an analytic concept, explaining how U.S. history and development differs from Europe (e.g., Lipset 1996; Warner 1993), to a normative concept, in which 
politicians must assert that the United States is the greatest nation on earth, now and in history (e.g., Cain 2011; GOP.com 2012). The nation was and is chosen by God, in this view, and was built by people answering a call to create a better society-and for some, of course, to build a Kingdom of God on Earth. Thus does our status as God's chosen intersect with the voluntarist principle in American religion and culture-people chose to take on the task of building a new society, as they chose to become Americans by moving here, as they choose righteousness and morality. ${ }^{5}$

Of course, this rendering of the American story, as a voluntary flight from a metaphorical Egypt to a Promised Land where a new world is possible, leaves out three very important populations - the indigenous peoples who were pushed aside or eradicated in order to make the New Jerusalem possible for European migrants, the tens of thousands of Mexicans who found themselves to be "Americans" after the Treaty of Guadalupe Hildalgo moved the United States-Mexico border in 1848, and the estimated 650,000 African slaves brought here against their wills to actually build the New Jerusalem. Again, we see an intersection of religion, race, and national identity - the story of building the nation is recounted as a religious mission, and told in such a way that it makes the white, especially European, peoples the protagonists of the narrative.

The worry about Obama being insufficiently "American" and potentially Muslim is amplified by Islam's status as an international religion with its "headquarters" not in the United States. Among the objections to Catholic immigrants in the 19th century (and one that had some resonance even to John Kennedy's 1960 presidential bid) was that their allegiance to the pope would trump concern for America and its people. Protestantism was seen as truly American, and democracy, local control, and congregational belonging seemed all of a piece (e.g., Williams 2007, 2009). There has never been any real concern in American politics and culture about a possible contradiction between Protestantism and American democracy and American identity. Indeed, the much beloved de Tocqueville credited American Protestantism with foundational support for political democracy. Other world religions, arriving later on these shores, have not had that privilege.

\section{American Civil Religion in the Neoliberal Moment}

It is interesting that much of the language and invectives hurled against Obama harkens back to older ideological battles, such as "socialist" or "Bolshevik" or "Nazi." The intellectual coherence of these labels is not what is at issue. The point, rather, is that these are distinctly "unAmerican" ideologies-ideologies that have directly threatened national survival and against which we have gone to war and Americans have died. These ideologies violate the tribal aspects of our civil religious understandings in that they have threatened us, they represent the enemy in a dangerous world, and preserving our people from these threats has required blood sacrifice. Just as the U.S. Civil War has been cast as blood atonement for the sin of slavery (see Stout 2006), the wars against Nazis and Communists required similar sacrifice to preserve national freedom and identity. "The tree of liberty must be refreshed from time to time with the blood of patriots and tyrants," Thomas Jefferson wrote, and opposition to Obama that tags him with these ideological labels do so as a way to dispute his status as a true member of the national community. ${ }^{6}$

\footnotetext{
${ }^{5}$ There is a potential tension between the idea of chosenness — as God-given and a product of divine will— and voluntarism and individual action. But these have been melded together in what Somers calls Anglo-American citizenship theory to produce a "social naturalism" - an experience of given-ness - that aligns with nationalism in composing an epistemology for the national imaginary (2008:277-82).

${ }^{6}$ For example, on August 11, 2009, New Hampshire resident William Kostric appeared outside President Obama's town hall meeting in Portsmouth with a loaded semiautomatic handgun strapped to his leg, and a sign that read: "IT IS TIME
} 
These older ideological terms also seem to miss some of the fundamental ways that the relationships between nations, states, markets, and the public and private spheres have been reshaped in the last three decades. We live increasingly in a "neoliberal" moment where economic liberalization, free trade and open markets, privatization, deregulation, and the decreasing size of the public sector undermine the redistributive power of the state, and its sovereignty (Berezin 2009; Brown 2010) to control people, markets, and borders.

Thus, use of labels such as "socialist" and "Nazi," like the birther and Muslim suspicions, reveals an anxiety about the future - a future in which religious and racial diversity means that the United States can no longer be easily or simply considered a white, Christian nation. As Barack Obama has literally embodied a disruption of the triangle of associations among religion, race, and national identity, these civil religious understandings of who we are and our special character in the world are at risk. These commitments to a particular vision of the nation have generated a deep concern about the sanctity of boundaries and borders, especially national borders. Immigration opponents see our borders as being "violated," and we must "seal the border" in order to "stop the invasion." There have been attempts to turn symbolic national boundaries into material, physical impediments, especially along the 2,000-mile United StatesMexico border (and in many other parts of the world; Brown 2010). This absorption with the border, with who may cross and under what conditions, occurs during an historical period in which actual nation-state borders are becoming less structurally consequential than ever before. As Andreas (2000) notes, national boundaries are increasingly irrelevant to the global flows of capital, labor, raw resources, and finished commodities. Trade agreements such as NAFTA (North American Free Trade Agreement), virtual networks and digitized capital, global transportation and communication infrastructures, and institutions of global governance have made nation-states less relevant than they have been in centuries. The imagined independence and self-sufficiency of the nation-state is now as mythological as the self-sufficiency of the autonomous rational actor in classical liberalism.

One response to this seems to be the reassertion of tribal identities and tribal violence within nation-states (or leading to the dissolution of nation-states) such as the violence in the Balkans following the break-up of Yugoslavia. Another response is a civil religious sacralization of the border-the division between "us" and "the other" - even as it becomes functionally less significant. Like the "frontier" in American mythology, the border has become for some the way we define ourselves, the edge of the land worth defending versus that land that is wild, untamed, and heathen. Here again we see the connection between religion, blood, and land. Our nation, our territory, and our rights as natural-born citizens are distinct, privileged, and justified with a civil religious presumption. Although collective religious violence has not afflicted the United States in this century, there has developed a clear political and religious justification for protecting our borders and elevating the welfare of our citizens-especially our citizens who literally embody the imagined moral center of our ethno-religious culture-above compassion for others.

The concept of civil religion has always presumed the nation-state. In Bellah's formulation or in those of his critics, the nation was assumed to be definable, in part because civil religion helped define it. Particularly in the United States, often thought to be a nation built on principles and ideals rather than birthright and territorial inheritance, civil religion was important to national identity and a valuable resource for societal cohesion as well as a resource for internal critique and social change. But the neoliberal moment presents a potential crisis for civil religion-it destabilizes borders, mixes populations, scrambles cultural heritages, and undermines clear presumptions of the authority and boundaries of the nation-state that is civil religion's ultimate referent. Under

TO WATER THE TREE OF LIBERTY!" When asked what message he was trying to send, Kostric stated, "I wanted people to remember the rights that we have and how quickly we're losing them in this country ... It doesn't take a genius to see we're traveling down a road at breakneck speed that's towards tyranny" (Horwitz 2009). 
these conditions, the choice may seem to some to be universal, global markets, or reassertion of tribal identities rooted in blood and land.

\section{Conclusions}

In contrast to this gloomy assessment that follows my lengthy attention to anti-immigrant arguments, anti-Muslim attitudes, and anti-Obama hostility, I offer a much-quoted passage from President Barack Obama's first inaugural address. Here we have a much different assumption about American society and a different implicit theory about the sources of social harmony:

For we know that our patchwork heritage is a strength, not a weakness. We are a nation of Christians and Muslims, Jews and Hindus - and non-believers. We are shaped by every language and culture, drawn from every end of this Earth; and because we have tasted the bitter swill of civil war and segregation, and emerged from that dark chapter stronger and more united, we cannot help but believe that the old hatreds shall someday pass; that the lines of tribe shall soon dissolve; that as the world grows smaller, our common humanity shall reveal itself; and that America must play its role in ushering in a new era of peace. (Obama 2009)

These are inspiring words. It was not hard to hope, particularly in 2009, that Barack Obama's election broke the older mold of American society's divisions. Indeed, some scholars see Barack Obama as reviving American civil religion. Most significantly, Gorski (2011) sees Obama as representing the tradition of civil religion that Bellah held up - a universalist, prophetic religious voice, built on covenant theology and civic republicanism, that balances religion and politics in such a way to be more inclusive than religious nationalism, but that also provides a better basis for solidarity than liberal secularism. Gorski calls this civil religion an "indigenous critical theory" and the "prophetic strand of our civil theology."

It is a provocative and hopeful argument, just as Obama's words carry that same spirit. Gorski provides a careful analysis that I hope reinvigorates debate about civil religion both conceptually and empirically. But it is difficult to see "civil religion" as at all coherent in our currently polarized political system, when appeals to "the American people" so often appear to be disingenuous attempts to mask particularized interests behind heady language, and the scope of the public sphere (and the legitimacy of the nation-state) are challenged both by global forces and deeply local resistances. Civil religious discourse, that is, the assemblages of images, symbols, arguments, and beliefs that connect the nation (and often the polity) to the transcendent and its purposes, continues to abound in our political culture. Political actors use it and many American respond, at least emotionally, to the national imaginary it portrays. But it is becoming increasingly difficult to ignore who is portrayed as included in the nation and who is identified for exclusion. The "boundaries of obligation" that Wong (2010) posits as the glue that identifies and holds together the national community are under constant assault by claims that such obligations are only legitimate when they are increasingly narrowed. There is a constant tug of war between a prophetic impulse - to hold the nation to account on the basis of a higher judgment, a nonsocietal standardand the religious nationalist core in which the group is sanctified, justified, and defended. The "group" in the American case has historically been white Christians; they have unproblematically worn the mantle of American identity and have been the gatekeepers of which other groups could aspire to do likewise. Membership in the national community-represented by the mixture of blood and land-has been rooted in a particular racial and religious identity.

Rather than conceptually exempting civil religion from this history and these contemporary impulses, we should keep the multiple strands of political exclusion and cultural inclusion contained within the concept. Civil religious discourse can critique society, and can call us to be better than we are. But civil religious discourse also works to heighten boundaries, and convinces people that those boundaries are natural and even sacred; it can provide the motivation for digging in behind them. Civil religion was born with "uncivil" impulses alongside its ennobling 
ones, and the struggle of contradictions is far from resolved. Blood and land lie at the core of religious conflict. They are as central to understanding religion in a neoliberal, globalized world as processes of fluidity, hybridity, and innovation.

As the political is part of the definition of what constitutes civil religion, we cannot shy away from all the political implications of that "faith." We must keep the struggle, and the potential for blood in the fight over land, in our research and theory.

\section{REFERENCES}

Anderson, Benedict. 1983. Imagined communities: Reflections on the origins and spread of nationalism. London: Verso. Andreas, Peter. 2000. Border games: Policing the U.S.-Mexico divide. Ithaca, NY: Cornell University Press.

Bail, Christopher A. 2012. The fringe effect: Civil society organizations and the evolution of media discourse about Islam. American Sociological Review 77(6):855-79.

Bakalian, Anny and Medhi Bozorgmehr. 2009. Backlash 9/11: Middle Eastern and Muslim Americans respond. Berkeley: University of California Press.

Barrett, Devlin. 2008. Obama bowls for Pennsylvania voters. Huffington Post March 30. Available at http:// www.huffingtonpost.com/2008/03/30/obama-bowling-for-voters-_n_94097.html, accessed February 4, 2013.

Bellah, Robert N. 1967. Civil religion in America. Daedalus 96(Winter):1-21.

- 1975. The broken covenant: American civil religion in a time of trial. Boston: Seabury Press.

1991. Beyond belief: Essays on religion in a post-traditionalist world. Berkeley: University of California Press.

Bennett, David H. 1988. The party of fear: From nativist movements to the new right in American history. New York: Vintage.

Berezin, Mabel. 2009. Illiberal politics in a neoliberal era: Culture, security and populism in the new Europe. New York: Cambridge University Press.

Berger, Peter L. 1967. The sacred canopy: Elements of a sociological theory of religion. New York: Doubleday.

Brodkin, Karen. 1998. How Jews became white folks and what that says about race in America. New Brunswick, NJ: Rutgers University Press.

Brown, Wendy. 2010. Walled nations, waning sovereignty. New York: Zone Books.

Burke, Daniel. 2012. Religion News Service October 16. Available at http://www.washingtonpost.com/national/onfaith/after-romney-meeting-billy-graham-website-scrubs-mormoncult-reference/2012/10/16/fa4ce826-17d1-11e2a346-f24efc680b8d_stor; , accessed November 3, 2012.

Cain, Herman. 2011. In defense of American exceptionalism: Unfortunately, some politicians have either forgotten or chosen to ignore the glory of our founding. American Spectator March. Available at http://spectator.org/archives/ 2011/03/03/in-defense-of-american-excepti, accessed February 26, 2013.

Coleman, John A. 1970. Civil religion. Sociological Analysis 31(1):67-77.

Cristi, Marcela. 2001. From civil to political religion: The intersection of culture, religion, and politics. Waterloo: Wilfrid Laurier University Press.

Cristi, Marcela and Lorne L. Dawson. 2007. Civil religion in America and in global context. In The SAGE handbook of the sociology of religion, edited by James A. Beckford and N. J. Demerath III, pp. 267-92. London: SAGE.

Demerath, N. J. III. 2003. Civil society and civil religion as mutually dependent. In Handbook of the sociology of religion, edited by Michele Dillon, pp. 348-58. New York: Cambridge University Press.

Demerath, N. J. III and Rhys H. Williams. 1985. Civil religion in an uncivil society. Annals of the American Academy of Political and Social Sciences 480(July):154-65.

Finke, Roger and Rodney Stark. 1992. The churching of America. New Brunswick, NJ: Rutgers University Press.

Fuist, Todd Nicholas and Rhys H. Williams. Forthcoming. Civil religion. In International encyclopedia of the social and behavioral sciences, 2nd ed., edited by James D. Wright. Amsterdam: Elsevier.

Glenn, Evelyn Nakano. 2011. Constructing citizenship: Exclusion, subordination, and resistance. American Sociological Review 76(1):1-24.

GOP.com. 2012. American exceptionalism. Republican platform: We believe in America. Available at http://www.gop. com/2012-republican-platform_exceptionalism/, accessed February 26, 2013.

Gorski, Philip S. 2011. Barack Obama and civil religion. Political Power and Social Theory 22(1):179-214.

Hammond, Phillip E. 1994. Forum: American civil religion revisited. Religion and American Culture 4(1):1-7.

Hatch, Nathan O. 1989. The democratization of American Christianity. New Haven, CT: Yale University Press.

Horwitz, Josh. 2009. Thomas Jefferson and the blood of tyrants. Huffington Post September 1. Available at http://www.huffingtonpost.com/josh-horwitz/thomas-jefferson-and-the_b_273800.html, accessed February 4, 2013.

Hughes, Richard T. 2003. Myths America lives by. Urbana: University of Illinois Press. 
Hughey, Matthew W. 2012. Show me your papers! Obama's birth and the whiteness of belonging. Qualitative Sociology 35(2):163-81.

Huntington, Samuel P. 2004. Who are we? The challenges to American national identity. New York: Simon and Schuster. Ignatiev, Noel. 1995. How the Irish became white. New York: Routledge.

Jacobson, Robin Dale. 2008. The new nativism: Proposition 187 and the debate over immigration. Minneapolis: University of Minnesota Press.

Jon, Marie. 2008. Looking at Obama and black liberation theology. Western Front America: A Journal of Conservative Social and Political Commentary February 19. Available at http://westernfrontamerica.com/2008/02/19/obamablack-liberation-theology/, accessed September 12, 2012.

Kornacki, Steve. 2012. The evangelical allergy to Mitt. Salon March 26. Available at http://www.salon.com/ 2012/03/26/the_evangelical_allergy_to_mitt/singleton, accessed September 12, 2012.

Lipset, Seymour Martin. 1996. American exceptionalism: A double-edged sword. New York: W.W. Norton.

Marty, Martin E. 1974. Two kinds of two kinds of civil religion. In American civil religion, edited by Russell E. Richey and Donald G. Jones, pp. 139-57. New York: Harper and Row.

Marvin, Carolyn and David W. Ingle. 1996. Blood sacrifice and the nation: Revisiting civil religion. Journal of the American Academy of Religion 64(4):767-80.

. 1999. Blood sacrifice and the nation: Totem rituals and the American flag. New York: Cambridge University Press.

McGreevy, John T. 1996. Parish boundaries: The Catholic encounter with race in the twentieth century urban North. Chicago: University of Chicago Press.

McVeigh, Rory. 2009. The rise of the Ku Klux Klan: Right-wing movements and national politics. Minneapolis: University of Minnesota Press.

Moore, R. Laurence. 1987. Religious outsiders and the making of Americans. New York: Oxford University Press.

Newton, Lina. 2008. Illegal, alien, or immigrant: The politics of immigration reform. New York: New York University Press.

Obama, Barack. 2009. Barack Obama's inaugural address. New York Times January 21.

Orsi, Robert Anthony. 1985. The Madonna of $115^{\text {th }}$ Street: Faith and community in Italian Harlem, 1880-1950. New Haven, CT: Yale University Press.

Peek, Lori. 2011. Behind the backlash: Muslim Americans after 9/11. Philadelphia: Temple University Press.

Penning, James M. 2009. Americans' views of Muslims and Mormons: A social identity theory approach. Politics and Religion 2(2):277-302.

Pew Forum on Religion and Public Life. 2012. Controversies over mosques and Islamic centers across the U.S. Available at http://features.pewforum.org/muslim/controversies-over-mosque-and-islamic-centers-across-the-us.html, accessed November 21, 2012.

Pew Research Center. 2008. Still think Obama is Muslim. Daily number. Available at http://www.pewresearch.org/dailynumber/still-think-obama-is-muslim/, accessed October 23, 2012. - 2010. Republicans believe Obama is a Muslim. Daily number. Available at http://www.pewresearch.org/dailynumber/republicans-believe-obama-is-a-muslim/, accessed October 23, 2012.

. 2012. Little voter discomfort with Romney's Mormon religion: Only about half identify Obama as Christian. Available at http://www.pewforum.org/politics-and-elections/2012-romney-mormonism-obamas-religion.aspx, accessed October 23, 2012.

Public Policy Polling. 2012. Very close race in both Alabama and Mississippi. Available at http: //www.publicpolicypolling.com/pdf/2011/PPP_Release_SouthernSwing_312.pdf, accessed September 15, 2012.

Putnam, Robert D. and David E. Campbell. 2010. American grace: How religion divides and unites us. New York: Simon and Schuster.

Rayfield, Jillian and Alex Seitz-Wald. 2012. The 10 most Islamophobic moments in the 2012 elections: From Allen West to Michele Bachmann, these are the most hateful examples of bigotry against Muslims this campaign. Salon.com October 20. Available at http://www.salon.com/2012/10/20/the_10_most_islamophobic_moments_in_ the_2012_elections/, accessed December 8, 2012.

Reimers, David M. 1998. Unwelcome strangers: American identity and the turn against immigration. New York: Columbia University Press.

Riccardi, Nicholas. 2008. Mormons feel the backlash over their support of Prop. 8: The campaign brought them closer to other religious groups. But it also made the church a political target. Los Angeles Times November 19. Available at http://articles.latimes.com/2008/nov/17/nation/na-mormons17.

Romney, Mitt. 2010. No apology: The case for American greatness. New York: St. Martin's Press.

Sarna, Jonathon D. (ed.). 1998. Minority faiths and the American Protestant mainstream. Urbana: University of Illinois Press.

Schrag, Peter. 2010. Not fit for our society: Immigration and nativism in America. Berkeley: University of California Press.

Singh, Amardeep. 2002. We are not the enemy: Hate crimes against Arabs, Muslims, and those perceived to be Arab or Muslim after September 11. Human Rights Watch 14(6):1-40. 
Skocpol, Theda and Vanessa Williamson. 2012. The Tea Party and the remaking of Republican conservatism. New York: Oxford University Press.

Smith, Anthony D. 2003. Chosen peoples. New York: Oxford University Press.

Somers, Margaret R. 2008. Genealogies of citizenship: Markets, statelessness, and the right to have rights. New York: Cambridge University Press.

Stout, Harry S. 2006. Upon the altar of the nation: A moral history of the Civil War. New York: Viking.

Theiss-Morse, Elizabeth. 2009. Who counts as an American? The boundaries of national identity. New York: Cambridge University Press.

Turner, Frederick Jackson. 1893. The significance of the frontier in American history. Report of the American Historical Association 1893(1):199-227.

Warner, R. Stephen. 1993. Work in progress toward a new paradigm for the sociological study of religion in the United States. American Journal of Sociology 98(5):1044-93.

. 2008. Parameters of paradigms: Toward a specification of the U.S. religious market system. Nordic Journal of Religion and Society 21(2):129-46.

Warner, R. Stephen and Judith G. Wittner (eds.). 1998. Gatherings in diaspora: Religious communities and the new immigration. Philadelphia: Temple University Press.

Weber, Max. 1958. Class, status, and party. In From Max Weber: Essays in sociology, edited by H. H. Gerth and C. Wright Mills, pp. 180-95. New York: Oxford University Press.

Williams, Rhys H. 1996. Religion as political resource: Culture or ideology? Journal for the Scientific Study of Religion 35(4):368-78.

. 2002. Religion, community, and place: Locating the transcendent. Religion and American Culture: A Journal of Interpretation 12(2):249-63.

- 2004. Religion and place in the Midwest: Urban, rural, and suburban forms of religious expression. In Religion and public life in the Midwest: America's common denominator, edited by Philip Barlow and Mark Silk, pp. 187-208. Walnut Creek, CA: Altamira.

- 2007. The languages of the public sphere: Religious pluralism, institutional logics, and civil society. Annals of the American Academy of Political and Social Sciences 612(July):42-61.

- 2009. Politicized evangelicalism and secular elites: Creating a "moral other." In Evangelicals and democracy in America, volume II: Religion and politics, edited by Steven Brint and Jean Reith Schroedel, pp. 143-79. New York: Russell Sage Foundation.

- 2010. Muslims in the U.S. after 9/11: Furthering an American Islam. Christian Century 127(12):32-36.

. 2011a. Creating an American Islam: Thoughts on religion, identity, and place. Sociology of Religion 72(2):12753.

. 2011b. Religion and social conflict: Traditions and change, blood and land. Paper presented at the American Sociological Association, Las Vegas, NV, August.

. 2012. Immigration and national identity in Obama's America: The expansion of "culture wars" politics. Canadian Review of American Studies 42(3):322-46.

Williams, Rhys H. and Susan M. Alexander. 1994. Religious rhetoric in American populism: Civil religion as movement ideology. Journal for the Scientific Study of Religion 33(1):1-15.

Williams, Rhys H. and Thomas J. Josephsohn. 2012. The "Ground Zero mosque" controversy: Religious pluralism, national identity, and the emotional politics of place. Paper presented at the Eastern Sociological Society, New York, February.

Williams, Rhys H. and C. James Park. 2005. The politics of immigration and visions of American national identity. Paper presented at the Eastern Sociological Society, Washington, DC, March.

— 2006. "Some may call it racism, we call it stopping immigration": Race in immigration reform discourse. Paper presented at the Eastern Sociological Society, Boston, MA, March.

Williams, Rhys H. and Gira Vashi. 2007. Hijab and American Muslim women: Creating the space for autonomous selves. Sociology of Religion 68(3):269-87.

Wong, Cara J. 2010. Boundaries of obligation in American politics: Geographic, national, and racial communities. New York: Cambridge University Press.

WorldNetDaily. 2008. Obama pastor's theology: Destroy "the white enemy." Available at. http://www.wnd.com/?pageId= 59230, accessed September 14, 2012.

Wuthnow, Robert. 1988. The restructuring of American religion: Society and faith since World War II. Princeton, NJ: Princeton University Press.

Zolberg, Aristide R. 2006. A nation by design: Immigration policy in the fashioning of America. New York and Cambridge, MA: Russell Sage Foundation and Harvard University Press. 